\title{
THE ASSESSMENT OF EFFICIENCY OF BLAST-FURNACE GRANULATED SLAG USED IN AUTOCLAVED AERATED CONCRETE MANUFACTURING
}

\author{
${ }^{1}$ Rudchenko D.G., Ph.D., \\ aeroc@aeroc.ua, ORCID: 0000-0003-2909-3864 \\ ${ }^{1}$ Dyuzhilova N.A., Ph.D., \\ Dyuzhilova.na@aeroc.ua, ORCID: 0000-0001-8602-1563 \\ ${ }^{1} L L C «$ Aeroc $»$ \\ 6, Promislova st., Obukhiv, 08700, Ukraine \\ ${ }^{2}$ Serdyuk V.R., Dr. Sc., Professor, \\ vasromvs@gmail.com, ORCID: 0000-0002-1694-8651 \\ ${ }^{2}$ Vinnytsia National Technical University \\ Khmelnytsky Highway, 95, Vinnytsia, 21000, Ukraine
}

\begin{abstract}
The current trends were analyzed and showed that the share of autoclaved aerated concrete in the market of wall materials was growing. The prospects for the use of blast-furnace granulated slag at autoclaved aerated concrete manufacturing were considered. At modern plants producing autoclaved aerated concrete, the existing pre-autoclave curing chambers for plastic hardening of raw materials reduces the duration of pre-autoclave curing time of the raw cake and intensifies the structure forming processes; thus, blast-furnace cement or blast-furnace granulated slag additives can be used in the casting manufacturing process. The comparative analysis of the cement clinker production and the blast-furnace slag formation was carried out. The methods assessing the hydraulic activity of blast-furnace granulated slag were presented.

The efficiency of blast furnace granulated slag that replaces partly Portland cement in the composition of aerated concrete with D300 density was experimentally studied. The organized experimental study envisaged that the return slurry containing lime and cement hydration products, as well as gypsum stone, is to be preserved in the aerated concrete mixture. Modern aerated concrete plants operate with the waste-free technology. The presence of $15-17 \%$ cut raw material in the aerated concrete raw mixture is mandatory at the casting technology of aerated concrete production.

A resource-saving technology for the production of autoclaved aerated concrete with blastfurnace granulated slag was proposed. The features of blast-furnace granular slag formation were considered and the slag optimal composition in the aerated concrete mixture is determined, which was $15-20 \%$. The replacing up to $10 \%$ of Portland cement with blast-furnace granulated slag during the production of D300 aerated concrete saves Portland cement and leads to a slight increase in the aerated concrete strength.
\end{abstract}

Keywords: autoclaved aerated concrete, blast-furnace granulated slag, energy saving.

Introduction. Autoclaved aerated concrete successfully combines constructive and thermal insulation properties. Final material with density of 150 to $700 \mathrm{~kg} / \mathrm{m} 3$ can be obtained with available raw materials, the same equipment and the same production flow chart. A wide range of constructive products and materials for various purposes is produced from aerated concrete, from large-sized wall panels, floor slabs, wall lintels to small-sized wall blocks and effective thermal insulation products.

Given the high constructive and heat-insulating properties of autoclaved aerated concrete, its relatively low cost in comparison with other wall materials, aerated concrete drives out from the construction market other traditional energy-demanding wall materials. About $40-50 \%$ of walls at modern low-rise and high-rise buildings in Ukraine, Russia and Poland were erected using autoclaved aerated concrete, and this figure is even higher in the Republic of Belarus.

The autoclaved aerated concrete manufacturing and use have energy-saving and environmental advantages over traditional wall materials (such as expanded-clay concrete, silicate brick and ceramic).

The competition in the autoclaved aerated concrete leads to searches for advanced manufacturing technologies that can reduce energy and raw material consumption and save costs. 
Cement and lime used at autoclaved aerated concrete manufacturing are highly energyconsuming materials. The actual specific consumption of fuel and energy for produced lime is $200.5 \mathrm{~kg}$ of equivalent fuel/ton, and for Portland cement is $121.7 \mathrm{~kg}$ of equivalent fuel/ton. Carbon dioxide emissions per 1 ton of cement produced in Ukraine equals 0.65 tons averagely. As for the "dry" method of cement production, this indicator varies from 0.41 to 0.5 tons of $\mathrm{CO}_{2}$ per 1 ton of cement.

These affordable, but energy-demanding binders are used at the autoclaved aerated concrete production, thus, several mandatory energy-demanding technological processes are envisaged: siliceous raw material grinding and continuous homogenization in slurry basins, autoclaving of aerated concrete in saturated steam at a temperature of about $200{ }^{\circ} \mathrm{C}$, transportation costs for a siliceous raw material, gypsum stone, binder, etc.

Blast-furnace granulated slag (BFGS), fly ash, and other additives have the great potential for the reduction of energy consumption associated with binder used at autoclaved aerated concrete manufacturing.

The study objective was: to reduce energy consumption and improve autoclaved aerated concrete operational properties by using blast-furnace granulated slag in manufacturing.

The review of recent research. It is well-known that the usage of BFGS, ash, nepheline sludge, natural active mineral additives save fuel and energy (by 15-40\%) at cement production, and also increase the output of traditional concrete with such binders. BFGS additive, as a binder component, has the greatest potential as for the hydraulic activity. This is due to the BFGS formation technology.

The industry for autoclaved aerated concrete production in the former USSR was mainly formed in the 60-70 years of the last century. The country held a leading position in Europe as for autoclaved aerated concrete studies in those years. At the same time, the main problems of national aerated concrete manufacturers at that time were a large share of manual labour, the lack of automation and the instability of many boilers, the vapour pressure of which ranged from 0.8 to $1.0 \mathrm{MPa}$, which was reflected on the aerated concrete quality.

The greatest contribution to the autoclaved concrete studies was made by the work of Yu.M. Butt [2-3], A.V. Volzhensky [4], P.I. Bozhenov [5], E.A. Galibina [6], S.A. Krzheminskiy [7], K.K. Kuatbaev [8], M.Ya. Krivitskiy [9], S.A. Mironov [10], E.S. Silaenkov [11] and many others.

The studies conducted in those years served as the basis for the development of the national science and were used to develop the Construction rules SN 277-70. Later, the Instructions for Aerated Concrete Products Manufacture SN 277-80 were put into effect in 1981 and became the main regulatory document for national manufacturers of autoclaved aerated concrete. This document is still valid in the ex-USSR countries, with the exception of the Republic of Belarus, which cancelled it and introduced the Technical Code of Good Practice TKP 45-5.03-137-2009 (02250) "Products from aerated concrete. Manufacturing Rules." According to SN 277-80, Portland cement, slag Portland cement with the content of $\mathrm{C}_{3} \mathrm{~S}$ not less than $50 \%$ and $\mathrm{C}_{3} \mathrm{~A}$ not higher than $6 \%$, quick lime not less than 3 grades, cement-lime, calcareous, slag-alkaline, highly basic ash binders and BFGS with hardening activators or as a component of mixed binders should be used as binders for aerated concrete.

Numerous studies $[2,4,5]$ show that not only blast-furnace granular slag can be used but also dump one, which do not active in normal hardening conditions. Their main components are gehlenite $\left(\mathrm{Ca}_{2} \mathrm{Al}(\mathrm{AlSi}) \mathrm{O}_{7}\right.$, akermanite $\mathrm{CA}_{2} \mathrm{Mg} \mathrm{Si}_{2} \mathrm{O}_{7}, \gamma-$ or $\beta$ - bi-calcium silicate, rankinite $\left(\mathrm{Ca}_{3} \mathrm{Si}_{2} \mathrm{O}_{7}\right)$ and pseudowollastonite $\left(\mathrm{Ca}_{3} \mathrm{Si}_{3} \mathrm{O}_{9}\right)$. Of these, only $\beta-2 \mathrm{CaO} \times \mathrm{SiO}_{2}$ is capable of hydration and hardening in general conditions. During autoclaving, pure gehlenite and glass of its composition do not harden, but the glass part is more active than crystalline gehlenite. When lime is added and steaming takes place, autoclaving of glass and crystalline gehlenite with $\mathrm{CaO}$ addition leads to the formation of a hydrogarnet, and pure gehlenite gives, apparently, hydro gehlenite. The strength of pure $\gamma \mathrm{C}_{2} \mathrm{~S}$ increases with pressure in the autoclave, while the addition of quartz to $\gamma \mathrm{C}_{2} \mathrm{~S}$ significantly increases the strength. Depending on its amount and vapour pressure, $\mathrm{CSH}(\mathrm{B})$, xonotlite is formed. During the hydration of pure $\gamma \mathrm{C}_{2} \mathrm{~S}$ in the temperature range $203-310^{\circ} \mathrm{C}$, only $\mathrm{C}_{2} \mathrm{SH}(\mathrm{C})$ is formed.

According to [12], milled granulated electric-thermophosphorus slag with specific surface up to $5000-6000 \mathrm{~cm}^{2} / \mathrm{g}$ in an autoclave with steam pressure of $16 \mathrm{kgf} / \mathrm{cm}^{2}$ has the activity of 200 $350 \mathrm{kgf} / \mathrm{cm}^{2}$. BFGS handled in a jet grinder at the mix classifier rotor speed of $\mathrm{n}=3000^{-1}$ increases 
the activity of blast-furnace slag and cement by 1.5 times: from 270 to $422 \mathrm{kgf} / \mathrm{cm}^{2}$ for blastfurnace slag, from 382 to $596 \mathrm{kgf} / \mathrm{cm}^{2}$ for cement [13].

The autoclaved aerated concrete production implies synchronized in time the end of the gas evolution process and the beginning of mixture setting. The uniformity and correctness of aerated concrete macropores largely determines the material physical and mechanical properties.

Even if silicate matrix itself has high strength, but if the gas formation process is ahead of the binder setting, defective masses are formed: sagging, cracks formed due to shrinkage processes.

It is possible to intensify plastic strengthening of aerated concrete raw material with BFGS additives by using chemical accelerators-additives or by raising the temperature of pre-autoclave curing. If pre-autoclave curing chambers are absent, it is problematic to use slag Portland cement or large dosages of BFGS additives at manufacturing, since the technological cycle of pre-autoclave curing of casted materials become longer in order to achieve plastic strength necessary for raw material cutting.

The review of existing practices for the autoclaved aerated concrete production until 1991 and nowadays shows that Portland cement and quick lime additives are usually used as binder; they, due to internal isothermal hydration, provides additional internal heating of the aerated concrete mixture and increase the raw material plastic strength. The aerated concrete manufacturers did not used slag Portland cement because the increase of aerated concrete plastic strength was delayed.

Not only national plants, but also in 10 plants bought in Poland, which produced $30-40 \%$ of the total aerated concrete in the USSR, did not have chambers for preliminary plastic strengthening of raw materials. Curing of casted materials took place directly at a workshop before cutting and feeding into an autoclave, which lengthened the technological cycle of pre-autoclave aerated concrete hardening.

The recommendations from numerous studies to use BFGS with various chemical acceleratorsadditives were never implemented into the industrial production of autoclaved aerated concrete.

As for modern plants producing aerated concrete blocks, the raw material is tilted and rotated to separate it into blocks and create caves for gripping by hands. In this case, the technological methods have to be implemented that accelerate plastic strengthening of raw material. The intensification of plastic strengthening takes place in a chamber for raw material plastic strengthening.

Autoclaved aerated concrete in the EU and countries of the former USSR is produced with the use, as a rule, of complex binder (cement + lime additive). There are few studies on influence of cements on the autoclaved aerated concrete properties, since it is generally accepted that Portland cement is the main stable component of binder [5, 14]. Publications appear very rarely in scientific journals [15].

The analysis of a large number of production tests carried out in [16] shows that it is possible to obtain concretes with a higher class as for compressive strength if Portland cements with mineral additives (slag) PC 42.5 - D20 or ЦЕM II / A-Ш are used. The authors propose expanding the range of Portland cements used in aerated concrete production, using cements with added slag. This increases the basic physical and mechanical properties and significantly reduces the manufacturing cost. Concrete obtained on the basis of purely clinker Portland cement had lower basic physical and mechanical characteristics than cement with added slag.

When pure clinker Portland cement was added to the raw material mixture, a clear maximum of strength was observed with the mixture activity of $11.5 \%$; while Portland cement with mineral additives showed low-sloped relationship between these indicators, moreover the block mechanical strength was almost at the same level for the activity in the range of 11.1-11.5\%.

In the work [17], the compositions of autoclaved aerated concrete with D200 - D500 density grades were optimized with electric steelmaking slag. The maximum strength, in comparison with the control compositions, had aerated concrete samples where 70-100 wt. \% Portland cement were replaced with grounded slag. The mineralogical composition was characterized by the presence of a belite phase $\left(\beta-2 \mathrm{CaO} \times \mathrm{SiO}_{2}, \gamma-2 \mathrm{CaO} \times \mathrm{SiO}_{2}\right)$, merwinite, monticellite, rankinite, as well as ironcontaining silicate phases.

The chambers of preliminary plastic strengthening of raw materials existing in the technological cycle at modern plants, equalizes the influence of slag Portland cement or BFGS additives to that of Portland cement at the stage of pre-autoclave aerated concrete curing.

Materials and research methods. The studies to test the effectiveness of BFGS additives for

Bulletin of Odessa State Academy of Civil Engineering and Architecture, 2020, no. 79, page 117-125 
autoclaved aerated concrete were carried out in the laboratory and industrial conditions of LLC "Aerok": Portland cement was partly replaced with grounded BFGS in the composition of aerated concrete with an estimated density of $300 \mathrm{~kg} / \mathrm{m}^{3}$.

Since the results obtained were of commercial value, the acticle does not reflect some of the technological regulations (technological parameters of raw materials, autoclaving modes, etc.).

During the research, the standard composition of raw materials for aerated concrete mixture was used, namely: river sand, gypsum stone, unslaked grounded lime, cement and a gasifier (aluminum powder).

Blast furnace granulated slag produced by PJSC "ArcelorMittal Kryvyi Rih" was used as BFGS additive. Its main characteristics are presented according to the information given in the slag manufacturer's certificate (Table 1).

Table 1 - Main characteristics of BFGS form PJSC "ArcelorMittal”

\begin{tabular}{|c|c|c|c|c|c|c|c|}
\hline \multirow{2}{*}{$\begin{array}{c}\text { Moisture, } \\
\%\end{array}$} & \multicolumn{6}{|c|}{ Chemical composition } & \multirow{2}{*}{$\begin{array}{l}\text { Radionuclide } \\
\text { content }\end{array}$} \\
\hline & $\mathrm{SiO}_{2}$ & $\mathrm{Al}_{2} \mathrm{O}_{3}$ & $\mathrm{CaO}$ & $\mathrm{MnO}$ & $\mathrm{MgO}$ & $\mathrm{TiO}_{2}$ & \\
\hline 5,5 & 38,74 & 7,18 & 44,8 & 0,37 & 7,84 & 0,29 & \multirow{3}{*}{94} \\
\hline 5,6 & 38,13 & 7,34 & 45,5 & 0,36 & 7,6 & 0,28 & \\
\hline 9,1 & 38,2 & 7,32 & 45,4 & 0,37 & 7,66 & 0,28 & \\
\hline
\end{tabular}

Modern aerated concrete plants operate with the waste-free technology and the cut aerated concrete raw material is returned to the production line for reuse. Thus, at assessment of the possibility to replace partly Portland cement with BFGS additive, return sludge present in the aerated concrete mixture must be taken into account. Lime, gypsum stone, cement contained in the mixture (highly basic calcium hydrosilicates as hydrosilicate gel formed at an early stage of hydration) also act as an activator of BFGS hydrational hardening during high-temperature autoclaving of aerated concrete.

To assess the possibility of partial replacement of Portland cement with BFGS additive, the aerated concrete mixture with the density of $300 \mathrm{~kg} / \mathrm{m}^{3}$ was moulded using the casting technology as follows. Raw sludge was removed from the industrial sludge basin. It contained ground sand, gypsum stone. $20 \%$ of the sludge (with the components contained in it) required for $1 \mathrm{~m}^{3}$ of aerated concrete was removed. The removed sludge was replaced by "artificial" sludge containing grounded BFGS and water, the water / solid ratio for the mixture was maintained. Cement consumption was reduced by $5-25 \%$ in control samples.

Grounded BFGS served as binder and, partially, as a siliceous component. Its specific surface was $\mathrm{S}=3800 \mathrm{~cm}^{2} / \mathrm{g}$. The mixture was further blended by a laboratory mixer.

Aluminium powder was introduced into the control and test mixture samples, all samples were cured in a curing chamber and autoclaved in an industrial autoclave in accordance with the technological regulations adopted at the enterprise.

At Aerok LLC, the required plastic strength of raw material was achieved at $50-54^{\circ} \mathrm{C}$ and relative air humidity up to $80 \%$. To maintain the temperature regime in the chambers of plastic strengthening, secondary heat was used.

Powerful steam generators at modern aerated concrete plants ensure the stabile working steam pressure in autoclaves in the automated mode, and the existing chambers for raw material plastic strengthening provides the potential for using of slag Portland cement or BFGS additive in the binder composition directly at autoclaved aerated concrete manufacturing. At the same time, conditions are created to intensify production by shortening the cycle of pre-autoclave aerated concrete curing and to improve autoclaving parameters.

For a more detailed study of the effect of the additive, we considered the features of BFGS formation. As it is well-known, approximately 1.3 tons of iron ore, 0.75 tons of coke, 0.25 tons of limestone are needed for production of 1 ton of pig iron. Empty acid rock of iron ore always contains $\mathrm{SiO}_{2}$ and $\mathrm{Al}_{2} \mathrm{O}_{3}$. Limestone (calcium carbonate $\mathrm{CaCO}_{3}$, or dolomitic limestone containing $\mathrm{MgCO}_{3}$ in addition to $\mathrm{CaCO}_{3}$ ) is used as the main fluxing stone at pig iron production. Slag is formed at the mutual reaction of iron ore rock with fluxing stone and coke ash during blast furnace production of pig iron; this slag is silicate and aluminosilicate melts covering pig iron surface. It is important to note that 
the blast furnace slag contains oxides: $\mathrm{CaO}, \mathrm{MgO}, \mathrm{SiO}_{2}, \mathrm{Al}_{2} \mathrm{O}_{3}(90-95$ wt.\%) and minor impurities of other oxides. During blast furnace slag granulation, crystallization of hydraulically inert components (gehlenite, $\mathrm{CaO} \times \mathrm{SiO}_{2}$ ) and the transition of $\beta-2 \mathrm{CaO} \times \mathrm{SiO}_{2}$ to the inactive form of $\gamma-2 \mathrm{CaO} \times \mathrm{SiO}_{2}$ stop. Slag acquires a glassy structure and is in an unstable state. Granular basic slag is able to interact with water and slowly harden, and the presence of self-hardening $2 \mathrm{CaO} \times \mathrm{SiO}_{2}$ and active $\mathrm{SiO}_{2}$ and $\mathrm{Al} 2 \mathrm{O}_{3}$ at elevated temperature provides them with hydraulic activity.

It should be noted that the temperature regime and raw materials composition at pig iron production is close to the process of cement clinker firing, which uses coal, limestone $(\mathrm{CaO}, \mathrm{MgO})$, clay components $\left(\mathrm{SiO}_{2}, \mathrm{Al}_{2} \mathrm{O}_{3} \mathrm{Fe}_{2} \mathrm{O}_{3}\right)$ and small amount of other oxides. If the clay component of the raw cement slurry does not have enough iron oxides, then iron oxides in the form of pyrite cinders are added to the mixture. Calcined cement clinker and blast furnace slag are cooled forcedly. The similarity of the formation technologies and composition for slag and cement clinker allows slag to be binder upon its contact with water. Rapid cooling of cement clinker from 1000$1050^{\circ} \mathrm{C}$ to about $50-60^{\circ} \mathrm{C}$ significantly affects its phase composition, microstructure and its hydration activity. By analogy with clinker, rapid cooling of blast-furnace slag does not allow silicic acid to bind with the basic oxides $\mathrm{CaO}$ and $\mathrm{Al}_{2} \mathrm{O}_{3}$ into crystalline compounds.

Quickly cooled slag is in a thermodynamically active, unstable, non-equilibrium state, and $\mathrm{SiO}_{2}$ and $\mathrm{Al}_{2} \mathrm{O}_{3}$ oxides with respect to $\mathrm{CaO}$ determine subsequently the slag hydraulic activity. BFGS can conditionally be presented as a specific type of "cement", which contains $\mathrm{CaO}$ bounded with various chemical compounds, including $\mathrm{C}_{2} \mathrm{~S}$ (one of the cement clinker minerals). As for its appearance, BFGS is coarse-grained porous sand with inclusions of small gravel grains.

The crushed main BFGS is slowly hydrated in its natural state, but at steam treatment (85$95^{\circ} \mathrm{C}$ ), the hydration hardening processes are accelerated, and with autoclaving and the presence of hardening activators, the strength of BFGS samples increases by 5-6 times. The work [4] showed that samples with normally hardened BFGS have the strength in the range of 0.8 to $5.8 \mathrm{MPa}$, and the strength of autoclaved samples was in the range from 12.2 to $36.1 \mathrm{MPa}$ (Table 2).

Table 2 - Strength of slag binders depending on hardening conditions

\begin{tabular}{|c|c|c|c|c|c|}
\hline \multirow{4}{*}{ Slag } & \multicolumn{2}{|c|}{ Binder composition, wt.\% } & \multicolumn{2}{c|}{ Compressive strength, MPa } \\
\cline { 2 - 6 } & Slag & Quicklime & $\begin{array}{c}\text { Two-water } \\
\text { gypsum }\end{array}$ & $\begin{array}{c}\text { After autoclaving at } \\
0.8 \mathrm{MPa}(3+8+3)\end{array}$ & $\begin{array}{c}\text { After hardening } \\
\text { above the water } \\
\text { (28 days) }\end{array}$ \\
\hline \multirow{4}{*}{ Waste dump } & 100 & - & - & 8,4 & 5,4 \\
\cline { 2 - 6 } & 90 & 10 & - & 18,7 & 3,5 \\
\cline { 2 - 6 } & 80 & 20 & - & 25,8 & 3,0 \\
\cline { 2 - 6 } Granules & 85 & 10 & 5 & 21,9 & 4,8 \\
\cline { 2 - 6 } & 100 & - & - & 28,3 & 3,0 \\
\cline { 2 - 6 } & 90 & 10 & - & 17,3 & 3,3 \\
\cline { 2 - 6 } & 80 & 20 & - & 15,3 & 10,8 \\
\hline
\end{tabular}

Granulated slag powders with a specific surface of $\mathrm{S}=0.6-0.8 \mathrm{~m}^{2} / \mathrm{g}$, with activity exceeding $300 \mathrm{kgf} / \mathrm{cm}^{2}$ can be obtained if BFGS dispersion is increased and setting and hardening accelerators are used $[18,19]$.

BFGS quality assessment. The following factors are the most widely used as slag chemical classifiers: basicity factor $\left(\mathrm{M}_{\mathrm{b}}\right)$; quality factor $\left(\mathrm{Q}_{\mathrm{f}}\right)$ and activity module $\left(\mathrm{M}_{\mathrm{ac}}\right)$.

$$
\begin{aligned}
& \mathrm{M}_{\mathrm{b}}=(\mathrm{CaO}+\mathrm{MgO}) /\left(\mathrm{SiO}_{2}+\mathrm{Al}_{2} \mathrm{O}_{3}\right) \\
& \mathrm{Q}_{\mathrm{f}}=\left(\mathrm{CaO}+\mathrm{MgO}+\mathrm{Al}_{2} \mathrm{O}_{3}\right) /\left(\mathrm{SiO}_{2}+\mathrm{TiO}_{2}\right) \\
& \mathrm{M}_{\mathrm{ac}}=\mathrm{Al}_{2} \mathrm{O}_{3} / \mathrm{SiO}_{2}
\end{aligned}
$$

P.I. Bozhenov [20] suggested using the $\mathrm{Kb}$ basicity coefficient for chemical assessment of raw materials:

$\mathrm{Kb}=\left[\left(\mathrm{CaO}+0,93 \mathrm{MgO}+0,59 \mathrm{~K}_{2} \mathrm{O}+0,9 \mathrm{Na}_{2} \mathrm{O}\right)-\left(0,55 \mathrm{Al}_{2} \mathrm{O}_{3}+0,35 \mathrm{Fe}_{2} \mathrm{O}_{3}+0,3 \mathrm{SO}_{3}+\right.\right.$ $\left.\left.1,28 \mathrm{CO}_{2}+1,33 \mathrm{P}_{2} \mathrm{O}_{5}\right)\right] / 0,93\left(\mathrm{SiO}_{2}+0,62 \mathrm{TiO} 2-0,83 \mathrm{FeO}\right)$. 
The expression in the numerator $(\mathrm{CaO}+0,93 \mathrm{MgO}+0,59 \mathrm{~K} 2 \mathrm{O}+0,9 \mathrm{Na} 2 \mathrm{O})$ shows the total content (in \%) of "conditional $\mathrm{CaO}$ ". The larger it is, the higher the hydraulic activity of the material. Subtrahend $-(0,55 \mathrm{~A} 12 \mathrm{O} 3+0,35 \mathrm{Fe} 2 \mathrm{O} 3+0,3 \mathrm{SO} 3+1,28 \mathrm{CO} 2+1,33 \mathrm{P} 2 \mathrm{O} 5)-$ determines the amount (in\%) of $\mathrm{CaO}$ bound by the corresponding oxides and not participating in the formation of silicates.

The quality of blast furnace slag at cement production is characterized by a quality factor and a percentage of basic oxides. Portland cement slag with a slag content of $25-40 \%$ is usually used under the same conditions as conventional Portland cement. Cements containing 40-80\% slag are used in massive hydraulic structures and structures exposed to aggressive water, as well as for the manufacture of products that are subjected to heat and moisture.

In 2015, Ukraine introduced the new state standard DSTU B.V.2.7-302: 2014 (EN 15167-1: 2006, NEQ) "Blast-furnace granulated slag for cements, concrete and mortars" [21]. As for chemical composition, BFGS consists mainly of the glass phase and should contain at least two thirds of the total weight of calcium oxide $(\mathrm{CaO})$, magnesium oxide $(\mathrm{MgO})$ and silicon oxide $\left(\mathrm{SiO}_{2}\right)$. The rest should be alumina $\left(\mathrm{Al}_{2} \mathrm{O}_{3}\right)$ along with small amount of compounds. The mass ratio $(\mathrm{CaO}+\mathrm{MgO}) /\left(\mathrm{SiO}_{2}\right)$ should be greater than 1.0. The glass content in blast-furnace granulated slag is determined in accordance with current regulatory and technical documentation.

The new state standard (DSTU) assesses BFGS activity with an activity indicator at the 7th day and the 28th day and divides it into three classes (Table 3). The ratio (in percent) of the compressive strengths of cement prisms made of test cement (50\% by weight) and grounded blast-furnace granulated slag (50\% by weight) and cement prisms made of $100 \%$ test cement compared at the same age. Compressive strength is determined according to state standards DSTU EN 196-1 or DSTU B 2.7-187.

Table 3 - Grades of grounded blast-furnace granulated slag [21]

\begin{tabular}{|c|c|c|}
\hline \multirow{2}{*}{ Grade } & \multicolumn{2}{|c|}{ Activity indicator, \%, not less } \\
\cline { 2 - 3 } & the 7th day & the 28th day \\
\hline 1 & 90 & 110 \\
\hline 2 & 70 & 90 \\
\hline 3 & 45 & 70 \\
\hline
\end{tabular}

The study results. The study results concerning the effect of Portland cement replacement with BFGS addition are shown in Fig. 1.

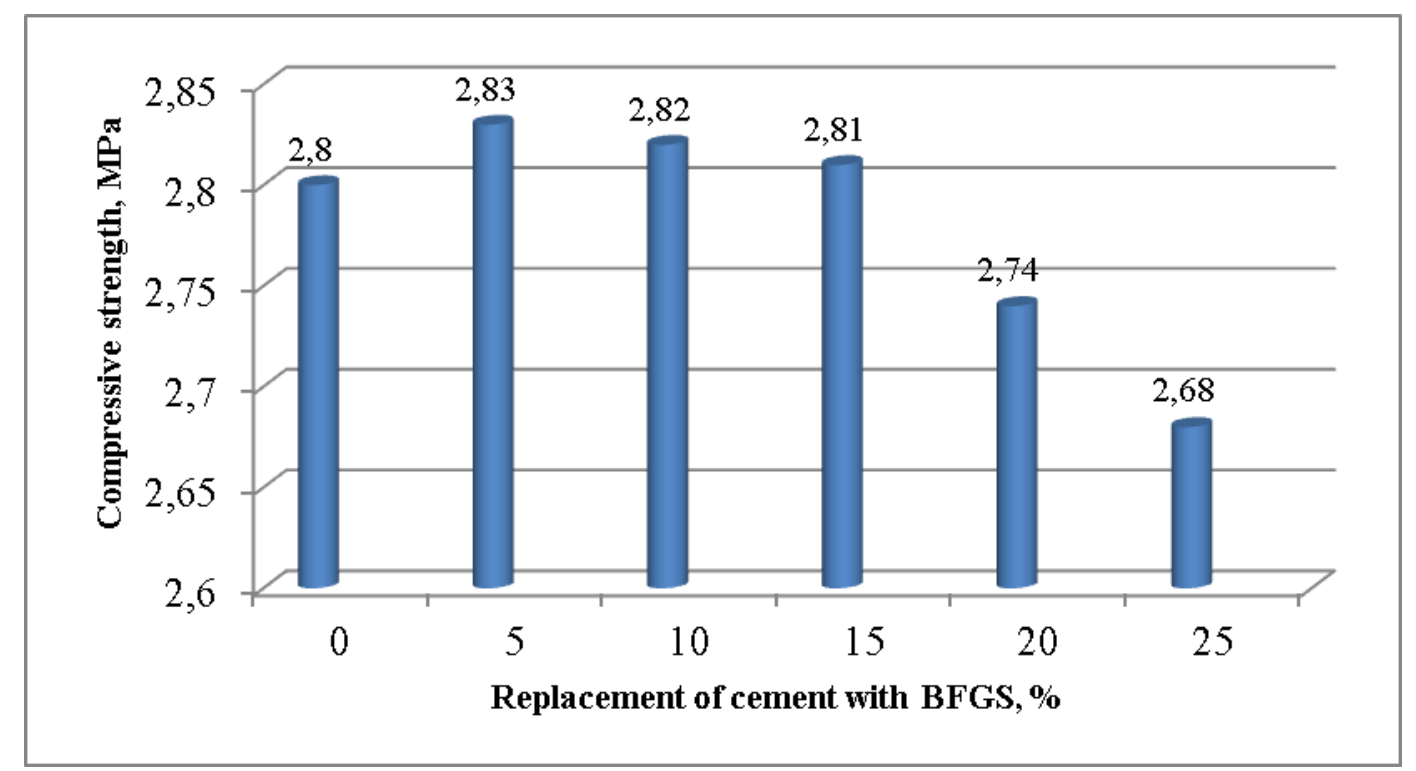

Fig. 1. The effect of Portland cement replacement with BFGS additive on the strength of D300 autoclaved aerated concrete 
As Fig. 1 shows, the replacement of Portland cement with BFGS leads to cement savings and slight increase of aerated concrete compressive strength. Replacing 10-15\% of cement with BFGS simultaneously solves several important practical problems, such as cement saving and industrial waste utilization.

Pre-curing chambers existing at modern plants manufacturing autoclaved aerated concrete are indented for plastic strengthening of raw material and reduces the autoclaving time, by activating the structure formation processes, so slag Portland cement with blast-furnace granulated slag additives can be used. The performed studies showed that the pre-autoclave curing time of raw material with BFGS additive increased slightly, by only 20 minutes but the necessary amount of cement decreased.

During the research, the features of blast-furnace granulated slag formation were considered and slag optimal amount in the aerated concrete mixture was determined, which was $15-20 \%$ of the total cement amount. As a result, the effective technology for autoclaved aerated concrete production with used blast-furnace granulated slag was developed and proposed.

Conclusions. Today and in the coming years, autoclaved aerated concrete will remain the main wall material, which has forced out traditional energy-consuming wall materials in the construction market. Therefore, scientific and applied works aimed at technological process improvement and improving autoclaved aerated concrete operational properties are timely and relevant.

The autoclaved aerated concrete production is relatively highly energy-consuming and more than half of this energy consumption falls onto mineral binders. BFGS used in binders for autoclaved aerated concrete allows manufacturers to reduce consumption of material and energy and to utilize the by-products of metal production accumulated in dumps. Energy cost saving by reducing the consumption of energy-demanding binder can also solve environmental problems because the greenhouse gas emissions into the atmosphere are reduced in this case.

BFGS is formed at pig iron production and these technological conditions are close to cement production. To use BFGS hydraulic potential, it must be grinded and processed in an autoclave at high temperature. The presence of a slag component in pure clinker Portland cement provides an improvement of autoclaved aerated concrete quality.

The conducted study confirmed the possibility to save 10-15\% of Portland cement by replacing it with BFGS additive, this increases slightly the strength of D300 autoclaved aerated concrete.

Our laboratory and industrial tests confirmed the relevance of using chambers for a preliminary plastic strengthening of aerated concrete manufactured with injection casting technology; thus, BFGS additives can be used to reduce Portland cement amount and energy consumption at production.

Thus, the reduction of energy consumption and environmental greenhouse gas emissions during autoclaved aerated concrete manufacturing, due to the use of active additives to cement, improves the production process and strengthen aerated concrete.

\section{References}

[1] K.V. Demchenko, "Sutnist ta neobhidnist ekologichnoyi modernizaciyi virobnictva v Ukrayini", Ekonomichnij analiz, Tom 28, no. 2, pp. 133-144, 2018.

[2] Yu.M. Butt, L.N. Rashkovich, Tverdenie vyazhuchih pri povyshennoj temperaturah. Moskva: Strojizdat, 1965.

[3] Yu.M. Butt, K.K. Kuatbaev, Dolgovechnost avtoklavnyh silikatnyh betonov. Moskva: Strojizdat, 1966.

[4] A.V. Volzhenskiy, Ju.S. Burov, V.S. Kolokolnikov, Mineralnye viazhushhie veshhestva. 3-e izd. Moskva: Strojizdat, 1979.

[5] P.I. Bozhenov, Tehnologija avtoklavnyh materialov. Leningrad: Strojizdat, 1978.

[6] E.A. Galibina, Avtoklavnye stroitelnye materialy iz othodov TES. Leningrad: Strojizdat, 1986.

[7] S.A. Krzheminskiy, N.K. Sudina, V.P. Varlamov, Avtoklavnaja obrabotka silikatnyh izdelij. Moskva: Stroizdat, 1974.

[8] K.K. Kuatbaev, P.A. Royzman, Yacheistye betony na malokvarcevom syr'e. Moskva: Strojizdat, 1972.

[9] M.Ja. Krivickiy, N.U. Levin, V.V. Makarichev, Yacheistye betony (tehnologija, svojstva i konstrukcii). Moskva: Strojizdat, 1972. 
[10] S.A. Mironov, M.Ja. Krivickij, L.A. Malinina i dr. Betony avtoklavnogo tverdenija. Moskva: Strojizdat, 1968.

[11] E.S. Silaenkov, Dolgovechnost' izdelij iz jacheistyh betonov. Moskva: Strojizdat, 1986.

[12] K.K. Kuatbaev, A.S. Saparbekov, "Tverdenie granulirovannyh jelektrotermofosfornyh shlakov v prisutstvii dobavok", Sbornik trudov Vniistrom, no. 15, pp. 3-15, 1978.

[13] V.P. Kravchenko, "Aktivacija domennyh shlakov", Visnyk Priazovs'kogo derzhavnogo tehnychnogo universytetu, Serija: Tehnichni nauki, vol. 2, pp. 17-20, 2010.

[14] G.L. Galkin, N.P. Sazhnev, Primenenie jacheistobetonnyh izdelij. Teorija i praktika. Minsk.: Strinko, 2006.

[15] V.A. Pinsker, V.P. Vylegzhanin, "Puti jekonomii cementa pri proizvodstve jacheistyh betonov", Stroitel'nye materialy, no. 1, pp. 43, 2008.

[16] M.V. Kaftaeva, Sh.M. Rahimbaev, N.D. Komarova, R.A. Alekenova, "O vlijanii cementa na osnovnye svojstva avtoklavnyh gazosilikatov", Izvestija VUZOV. Severokavkazkiy region. Tehnicheskie nauki, no. 4, pp. 107-111, 2015.

[17] E.I. Baranovskaya, A.A. Mechay, "Tehnologija avtoklavnogo jacheistogo betona s ispol'zoavaniem jelektrostaleplavil'nogo shlaka", Trudy BGTU, no. 3, pp. 81-85, 2016.

[18] V.P. Kravchenko, V.A. Strutinskij, "Gidravlicheskaja aktivnost' domennyh shlakov", Stal', no. 1, pp. 94-95, 2007.

[19] V.I. Korneev, I.N. Medvedev, A.G. Il'jasov, "Uskoriteli shvatyvanija i tverdenija portlandcementa na osnove oksidov i gidrooksidov aljuminija", Cement i ego primenenie, no. 2, pp. 40-42, 2003.

[20] P.I. Bozhenov, Kompleksnoe ispol'zovanie mineral'nogo syr'ja i jekologija. Moskva: Izd. Assoc. stroit vuzov, 1994.

[21] (EN 15167-1:2006, NEQ). DSTU B V.2.7-302:2014. Shlak domenniy granul'ovanij dlya cementiv, betoniv i budivel'nih rozchiniv. Tehnichni umovi ta ocinka vidpovidnosti Kyiv. Minregionbud. 2015.

\title{
ОЦІНКА ЕФЕКТИВНОСТІ ВИКОРИСТАННЯ ДОМЕННИХ ГРАНУЛЬОВАНИХ ШЛАКІВ В ТЕХНОЛОГІЇ ВИРОБНИЦТВА АВТОКЛАВНОГО ГАЗОБЕТОНУ
}

\author{
${ }^{1}$ Рудченко Д.Г., к.Т.н., \\ aeroc@ aeroc.ua, ORCID: 0000-0003-2909-3864 \\ ${ }^{1}$ Дюжилова Н.О., к.Т.н., \\ Dyuzhilova.na@aeroc.ua, ORCID: 0000-0001-8602-1563 \\ ${ }^{1}$ ТОВ «Аерок» \\ вул. Промислова, 6, м. Обухів, 08700, Україна \\ ${ }^{2}$ Сердюк В.P., д.т.н., професор, \\ vasromvs@gmail.com, ORCID: 0000-0002-1694-8651 \\ ${ }^{2}$ Вінницький національний технічний університет \\ Хмельницьке шосе, 95, м. Вінниця, 21000, Україна
}

Анотація. Проаналізовано сучасні тенденції збільшення частки автоклавного газобетону в структурі ринку стінових матеріалів. Розглянуто перспективи використання доменних гранульованих шлаків в технології виробництва автоклавних ніздрюватих бетонів. Встановлено, що влаштування на сучасних заводах 3 виробництва автоклавних газобетонів камер попереднього дозрівання для набору пластичної міцності скорочує тривалість доавтоклавної витримки масиву сирцю та інтенсифікуючи процес структуроутворення дає можливість використання шлакопортландцементу або добавок доменного гранульованого шлаку в литтьовій технології виробництва. Проведено порівняльний аналіз виробництва цементного клінкеру i утворення доменного шлаку. Показані методи оцінки гідравлічної активності доменних гранульованих шлаків.

Наведено результати експериментальних досліджень оцінки по ефективності застосування доменних гранульованих шлаків в складі газобетонної суміші з маркою по щільності D300 шляхом заміни частини портландцементу. При проведенні досліджень передбачалося збереження в складі газобетонної суміші зворотнього шламу, що містить продукти гідратації

Bulletin of Odessa State Academy of Civil Engineering and Architecture, 2020, no. 79, page 117-125 
вапна i цементу, а також гіпсового каменю. Сучасні газобетонні заводи працюють за безвідходною технологією. Наявність в складі сировинної газобетонної суміші $15-17 \%$ зрізаного сирцю є обов'язковою складовою при литтєвій технології виробництва газобетону.

Запропоновано ресурсозберігаючу технологію по виробництву автоклавного ніздрюватого бетону з використанням доменного гранульованого шлаку. Розглянуто особливості утворення доменного гранульованого шлаку і визначена оптимальна його кількість в складі газобетонної суміші, яка становить 15-20\%. Встановлено, що заміна до 10\% портландцементу доменним гранульованим шлаком при виробництві газобетону щільності D300 забезпечує економію портландцементу і веде до незначного підвищення міцності газобетону.

Ключові слова: ніздрюватий бетон, газобетон, доменний гранульований шлак, енергозбереження.

\title{
ОЦЕНКА ЭФФЕКТИВНОСТИ ИСПОЛЬЗОВАНИЯ ДОМЕННЫХ ГРАНУЛИРОВАННЫХ ШЛАКОВ В ТЕХНОЛОГИИ ПРОИЗВОДСТВА АВТОКЛАВНОГО ГАЗОБЕТОНА
}

\author{
${ }^{1}$ Рудченко Д.Г., к.т.н., \\ aeroc@aeroc.ua, ORCID: 0000-0003-2909-3864 \\ ${ }^{1}$ Дюжилова Н.А., к.т.н., \\ Dyuzhilova.na@aeroc.ua, ORCID: 0000-0001-8602-1563 \\ ${ }^{1}$ ООО «Аэрок» \\ ул. Промышленная, 6, г. Обухов, 08700, Украина \\ ${ }^{2}$ Сердюк В.P., д.Т.н., профессор, \\ vasromvs@gmail.com, ORCID: 0000-0002-1694-8651 \\ ${ }^{2}$ Винницкий национальный технический университет \\ Хмельницкое шоссе, 95, г. Винница, 21000, Украина
}

\begin{abstract}
Аннотация. Проанализированы современные тенденции увеличения доли автоклавного газобетона в структуре рынка стеновых материалов. Рассмотрены перспективы использования доменных гранулированных шлаков в технологии производства автоклавных ячеистых бетонов. Установлено, что наличие на современных заводах по производству автоклавных газобетонов камер предварительного созревания для набора пластической прочности сырца сокращает продолжительность доавтоклавной выдержки массива и интенсифицируя процессы структурообразования дает возможность использования в технологии производства шлакопортландцемента или добавок доменного гранулированного шлака. Проведен сравнительный анализ производства цементного клинкера и образования доменного шлака. Показаны методы оценки гидравлической активности доменных гранулированных шлаков.

Приведены результаты экспериментальных исследований оценки по эффективности применения доменных гранулированных шлаков в составе газобетонной смеси с маркой по плотности D300 путем замены части портландцемента. При проведении исследований предусматривалось сохранение в составе газобетонной смеси возвратного шлама, содержащего продукты гидратации извести и цемента, а также гипсового камня. Современные газобетонные заводы работают по безотходной технологии. Наличие в составе сырьевой газобетонной смеси $15-17 \%$ срезанного сырца является обязательной составляющей литьевой технологии производства газобетона.

Предложена ресурсосберегающая технология производства автоклавного ячеистого бетона с использованием доменного гранулированного шлака. Рассмотрены особенности образования доменного гранулированного шлака и определена оптимальная его дозировка в составе газобетонной смеси, которая составляет 15-20\%. Установлено, что замена до $10 \%$ портландцемента доменным гранулированным шлаком при производстве газобетона плотности D300 обеспечивает экономию портландцемента и ведет к незначительному повышению прочности газобетона.
\end{abstract}

Ключевые слова: ячеистый бетон, доменный гранулированный шлак, энергосбережение.

Стаття надійшла до редакції 16.05.2020

Bulletin of Odessa State Academy of Civil Engineering and Architecture, 2020, no. 79, page 117-125 